DOI https://doi.org/10.18551/rjoas.2021-02.20

\title{
ADOPTION OF CLIMATE SMART AGRICULTURE AMONG FOOD CROP FARMERS IN BIRNIN-KUDU LOCAL GOVERNMENT AREA, JIGAWA STATE, NIGERIA
}

\author{
Mailumo S.S.* \\ Department of Agricultural Extension and Management, Federal College of Forestry, Nigeria \\ Onuwa G.C. \\ Research Coordinating Unit, Forestry Research Institute of Nigeria, Nigeria
}

\section{Oyewole S.}

Department of Agriculture Economics, University of Jos, Nigeria

*E-mail: drmailumo247@gmail.com

\begin{abstract}
This study used multinomial logit regression to determine the factors that drive the choice of major adaptation measures by famers in Birnin-Kudu, Jigawa State. The study used multistage sampling procedure to select 120 food crop famers in the area. Data analysis was done using descriptive statistics, likert scale and Multinomial logit regression model. From the results, the level of awareness of climate smart agriculture was high and several adaptation strategies were consciously or unconsciously adopted and practiced by the famers. The CSA identified were early planting, mixed cropping, cover cropping, multiple planting dates, dry season farming, planting improved variety and late planting. Farmers confirmed that based on observation, climate change has led to a reduction in crop yields over the years. The multinomial logit result indicated that factors that influence the adoption of the CSA practices are age, headship of households, education, farm size, experience in farming, household size, and income from farming. Finally, the study established that there is high level of awareness of the debilitating effects of climate change among the farmers. To encourage the famers to adopt CSA, the calls for education of farmers on climate change and variability cannot be overemphasized.
\end{abstract}

\section{KEY WORDS}

Adoption, climate, smart, food, multinomial logit.

Climate change is the significant variation of the mean state of climate relevant variables such as temperature, precipitation and wind in certain period of time, usually over 30 years Intergovernmental Panel on Climate Change (IPCC, 2013). The changes in the climate can be natural; resulting from the climate system and its internal dynamics, climate can also be induced through external influence. Climate change has recently shifted from high level advocacy on "the need to act" to regional, country and community level responses on "how to adapt" (Schiermeier, 2007; Wilby, 2007). African countries are said to be more at risk from climate change effects because of a number of factors including limited skills and equipment for disaster management, limited financial resources, weak institutional capacity and heavy dependence on rain-fed agriculture (Rockstrom, 2000). As noted by Scholes et al. (2006), climate change threatens to intensify development challenges already confronting the Sub-Saharan Africa region including food security. Hence many have argued the need for more detailed information on the likely impacts of climate change on agricultural systems (Moore et al., 2009; Seitz and Nyangena, 2009).

Climate change is predicted to have great impact on agriculture. There is growing consensus that in the coming years, the world would continue to experience higher temperatures and changes in rainfall patterns. Climate change scenario was no threat to life and environment before the industrial revolution but has been rapidly changing since then. Today, the reality is that climate change is going to get worse than it was before now (FAO, 
2010). The effects of this will be more on agriculture production, as it could lead to low agriculture production and agriculture productivity, food insecurity, disease outbreak, increasing unemployment, youth restiveness and human malnutrition if urgent intervention is not put in place to checkmate it. Climate change is already affecting crop yield and livestock production in many parts of the world particularly in low-income countries, where climate is the primary determinant for agriculture productivity and adaptive capacities are low.

Agriculture is the single largest employer of labour in the world today, providing livelihoods for 40 percent of the global population, it is the largest source of income and Job creation for poor rural households. In Africa $65 \%$ of the population is employed in Agriculture with women constituting $50 \%$ of this number, but climate change is having significant impact on Africa agriculture because of inadequate preparation to cushion the effects, which are becoming more frequent and severe; threatening the reliability and productivity of agriculture, exacerbating the already extreme levels of poverty, and reinforcing persistent inequity and chromic under-nutrition. Over the decades some $75 \%$ of crop diversity has been lost from farms worldwide as a result of climate change (IPCC, 2013).

Agricultural production remains the main source of livelihoods for most rural communities in developing countries and sub-Saharan Africa in particular. Here, agriculture provides a source of employment for more than 60 percent of the population and contributes about 30 percent of Gross Domestic Product (GDP) (Kandlinkar and Risbey 2000). Climate change will have greater negative impacts on poorer farm households as they have the lowest capacity to adapt to changes in climatic conditions.

Adaptation measures are therefore important to help these communities to better face extreme weather conditions and associated climatic variations (Adger et al., 2003). Adaptation has the potential to significantly contribute to reductions in negative impacts from changes in climatic conditions as well as other changing socioeconomic conditions, such as volatile short-term changes in local and international markets (Kandlinkar and Risbey 2000). Therefore, an analysis of adaptation options and constraints to adaptation is important for the agricultural communities of western Africa.

Climate-smart agriculture (CSA) is one approach that has been championed as the "holy grail" of agricultural development (Naess, 2011) ensuring that agriculture is key to climate change adaptation and mitigation (Wollenberg et al., 2011; Beddington et al., 2012). Climate-smart agriculture is derived from the acronym SMART, $\mathrm{S}$ stands for specific, $\mathrm{M}$ stands for measureable, A for achievable, R for reliable and T for timely (McCarthy et al., 2012). According to the Food and Agriculture Organization (FAO) (2010), CSA is a method of agriculture that sustainably increases productivity, resilience (adaptation), reduces/removes greenhouse gases (mitigation) while enhancing the achievement of national food security and development goals. There are three main pillars to any CSA approach: the sustainable increase in agricultural productivity and incomes; adapting and building resilience to climate change; and reducing and/or removing greenhouse gases emissions. As such, agriculture is considered to be "climate-smart" when it achieves these three objectives. This concept is therefore a good way to unite the agendas of agriculture, development and climate change under one brand. The CSA approach has been widely championed with a rapid uptake of the concept by the international environments, national entities, local institutions and cultures (Ostrom et al., 2007).

\section{THEORETICAL BACKGROUND}

Climate Smart Agriculture (CSA) is an approach to guide the management of agriculture in the era of climate change. The concept was first launched in 2009 , and since then has been reshaped through inputs and interactions of multiple stakeholders involved in developing and implementing the concept. CSA aims to provide globally applicable principles on managing agriculture for food security under climate change that could provide a basis for policy support and recommendations by multilateral organizations, such as UN's FAO. The major features of the CSA approach were developed in response to debates and controversies in climate change and agricultural policy for sustainable development. 
The increased frequency and intensity of extreme events is clearly one of the most important game-changing effects of climate change. Recent work by Fischer and Knutti (2015) on the link between climate change and extreme events estimated that $75 \%$ of extreme hot days and $18 \%$ of days with heavy rainfall worldwide can be explained by the warming we've seen over the industrial period. The same study also finds that the probability of extreme events increases nonlinearly with increasing global warming. For instance, the probability of an extreme hot day under a scenario of $2{ }^{\circ} \mathrm{C}$ increase over pre-industrial levels is almost double the probability at a $1.5^{\circ} \mathrm{C}$ increase, and is more than five times higher than with today's climate (FAO, 2018). Essentially, the vulnerability of the agricultural sector to adverse events is increasing at a rapid, steep and broad scale, which implies a need for innovative measures to reduce the exposure and sensitivity of the agricultural sector, and also to increase adaptive capacity.

In principle farmers' adaptation to climate change can be modeled using the framework of technology adoption. Generally adoption of technologies depends on a number of factors such as financial incentives, access to extension services and markets but also perceptions and behavior. There is, however, a difference between conventional technology adoption and climate adaptation. While adoption of new technologies mostly aims at increasing profits, adjustments to climate change are often undertaken to reduce risks and to minimize future losses, both of which are directly affected by perceptions of current and future change. It is therefore necessary to incorporate farmers' perception of climate change in an adoption model (Maddison 2007).

Weber (2010) found that people's perception of climate change both in terms of its existence and extent are shaped by learning from personal experience and by making use of statistical information. The formation of perceptions depends on the trust that people attribute to climate scientists and their social amplifiers. Perceptions, however, are only meaningful when they can be linked to actual adaptation measures (Reilly and Schimmelpfennig 1999).

Theoretical insights about the relationship between risk perception and the adoption of risk management actions can be gained from the psychology and economics literature. The psychology literature (e.g. Fuster 2002) refers to the perception-action cycle, where people prepare themselves for perceived future outcomes, including the perceived seriousness of potential outcomes. From the economics literature, we can learn that it is necessary to distinguish between gain and loss domain (Kahneman et al. 1990). Tversky and Kahneman (1992) have shown people tend to weigh potential losses higher than potential gains.

Traditionally, adoption decisions have been analyzed in a utility maximization framework with profit as the primary motive (Greene 2003; Norris and Batie 1987). Accordingly, a technology is adopted when the perceived utility or net profit from adoption is significantly larger than not adopting it. The adoption decision is subject to a set of exogenous variables such as household characteristics, socioeconomic and physical factors (Feder et al. 1985). More recent models of climate change adaptations have been developed for African countries (Maddison 2007; Deressa et al. 2008; Gbetibouo 2009). These models incorporated climate change perceptions as explanatory variable. We follow this approach to model the factors that influence climate change perceptions and related adaptation measures as well as to explain specific climate change adaptation measures.

\section{METHODS OF RESEARCH}

The study was carried out in Birnin-Kudu Local Government Area in Jigawa State. It is located in northern Jigawa State, Nigeria. It is exactly 136 kilometers from Kano, along the old Kano-Maiduguri Road and about 35km from the capital of Jigawa State, Dutse. BirninKudu is situated on latitude $11.45^{\circ}$ north and longitude $9.5^{\circ}$ east. It stands at an elevation of 474 meters above the sea level. Birnin-Kudu has an estimated population of 421,143 (2016 projected from 2006 census). It is situated within the sub-saharan part of northern Nigeria, typical of this region, the land is almost flat with few undulating hills and scattered rock extrusions. There are a few streams that transverse the length and breadth of the Local Government Area. The climate is hot and dry during summer, cold and dusty in the winter. 
Rain usually falls between the months of May and September allowing for subsistence farming of mainly cereals such as guinea corn, millet, rice, and maize and cash crops such as beniseed, ground nut, soya beans, and cassava. It is endowed with rivers, ponds, lakes, forest and fertile soil. The major occupation in the area is farming, cattle rearing and fishing. The languages usually spoken by the people are Hausa and Fulani

Birnin-kudu Local Government Area was purposively selected out of the Local Government Areas in Jigawa State because about $80 \%$ of the inhabitants were engaged in agriculture. The Local Government Area has twelve (12) districts, out of which Three (3) were selected using random sampling technique. Ten (10) villages were selected randomly out of the Three (3) districts. Forty (40) questionnaires were administered in each of the three districts on crop famers who were selected randomly to make the overall sample size of 120 respondents for the study.

The main source of information was primary data. The data was collected through the administration of questionnaire complemented by an interview during the survey period. The questionnaire were based on the objectives of the study. The data were analyzed is achieved using descriptive statistics, likert scale and multinomial logit (MNL) model.

Multinomial logit (MNL) model was employed in the estimation of the determinants of the choice of climate change adaptation strategies by food crop farmers because it is widely used in adaption decision studies involving multiple choices and is easier to compute than its alternative, the multinomial probit model. It specifies the following relationship between the probability of choosing an option and the set of explanatory variables, X (Greene 2003):

$$
\operatorname{pr}\left(y_{i}=j\right)=\frac{e \beta_{j x_{i i}}}{1+\sum_{m=0}^{6} e^{\beta m x i j}}, j=0,1,2,3
$$

Where: $\beta j$ is a vector of parameters that relates the socio-economic, farm and institutional characteristics $x j$ to the probability that $Y j=j$. Because the probabilities of the six (6) main climate change adaptation strategies must sum to one, a convenient normalization rule is to set one of the parameter vectors, say $\beta_{0}$ equal to zero $\left(\beta_{0}=0\right)$ (Greene, 2000). The probabilities for the six (6) alternatives then become:

$$
p_{j}=\operatorname{Pr}\left(y_{i}=j\right)=\frac{e \beta_{j x_{i i}}}{1+\sum_{m=0}^{6} e^{\beta m x i j}}, j=0,1,2,3
$$

The estimated parameters of a multinomial logit system are more difficult to interpret than those of a bivariate (or binomial) choice model. Insight into the effect that the explanatory variables have on the climate change adaptation strategies choice can be captured by examining the derivative of the probabilities with respect to the $\mathrm{K}^{\text {th }}$ element of the vector of explanatory variables. These derivatives are defined as (Greene, 2000):

$$
\frac{\partial \operatorname{Pr}\left(y_{i}=j\right)}{\partial x_{i k}}=p_{j}\left[\beta_{j k}-\sum_{m=0}^{6} \operatorname{Pr}\left(y_{i}=m\right) \beta_{j k}\right] j=0,1, \ldots \ldots, 6, k=1, \ldots, k
$$

Clearly, neither the sign nor the magnitude of the marginal effects need bear any relationship with the sign of coefficients. The $\mathrm{Yi}$ is the probability of choosing a climate change adaptation strategy. The following are the main Climate Smart Agriculture (CSA) practices among the food crop farmers with their assigned values:

- 1 = for using different or multiple crop varieties;

- 2 = for cover cropping (i.e. crops such as cowpea groundnuts, Bambara nuts leguminous crops);

- $3=$ for change in timing of operations/ change in planting dates (i.e. multiple planting dates);

- 4 = for irrigation or dry season farming;

- 5 = for planting of improve crop varieties; 
- $6=$ for planting when the rains are fully establish (late planting).

A 3-point likert rating scale was used to measure the perception of the effect of climate change to the adoption of climate smart agriculture using $1=$ not intense $(\mathrm{NI}), 2=$ moderately intense $(\mathrm{MI})$ and $3=$ highly intense $(\mathrm{HI})$. To determine the mean, Likert scale levels of each item was calculated by multiplying the frequency of each response pattern with its appropriate nominal value and divide the sum with the number of respondent to the items. This can be summarized as follows:

$$
X s=\sum f n / N
$$

Where: $X s=$ mean score; $\Sigma=$ Summation; $f=$ frequency; $N=$ number of the respondent.

\section{RESULTS AND DISCUSSION}

Result in Table 1 shows that majority (78\%) of the farmers in the study area mostly adopt mixed cropping as a Climate Smart Agriculture practice followed by early planting (73\%) and cover cropping (69\%). Another (63\%) adopt improved crop varieties, followed by irrigation farming (58\%) while late planting, agro forestry, and wind breakers were other CSA practices adopted by the farmers in varying degrees to mitigate the effect of climate change on crop agriculture. This implies that the farmers are conscious of the effect of climate change on crop agriculture and they make effort mostly deliberately to mitigate its effects.

Table 1 - Distribution showing coping strategies and mitigation measures adopted by the respondent $(n=120)$

\begin{tabular}{|c|c|c|}
\hline Variables & Frequency & Rank \\
\hline Mixed cropping & 94 & $781^{\text {st }}$ \\
\hline Early planting & 87 & $732^{\text {nd }}$ \\
\hline Cover cropping & 83 & $693^{\text {rd }}$ \\
\hline Improve crop varieties & 76 & $634^{\text {th }}$ \\
\hline Irrigation farming & 69 & $585^{\text {th }}$ \\
\hline Late planting & 64 & $536^{\text {th }}$ \\
\hline Agro forestry & 45 & $387^{\text {th }}$ \\
\hline Wind breakers. & 41 & $348^{\text {th }}$ \\
\hline
\end{tabular}

The results of the estimates of the marginal effects along with the levels of statistical significance from the MNL are presented in Table 2. The dependent variable in the empirical model for this study is the choice of adoption of Climate Smart Agriculture practices from the set of strategies and the reference group assumed is the zero adopters. From the result, a number of factors had significant effect on the various climate adaptation strategies and this is discussed below.

The Likelihood ratio statistic (as indicated by $X^{2}$ statistic) is highly significant $(P<0.00)$, suggesting that the model has a strong explanatory power. As indicated earlier, the parameter estimates of MNL model provide only the direction of the effect of the independent variables on the dependent (response) variable: estimates do not represent actual magnitude of change or probability. Thus, the marginal effects from the MNL which measure the expected change in probability of a particular choice being made with respect to a unit change in an independent variable, are reported and discussed. In all cases the estimated coefficients should be compared with the base category (early planting), this is only used as the reference point against which other Climate Smart Agriculture adaptation strategies are contrasted.

From Table 2, farmer's decision to adopt mixed cropping as a CSA practice is influence by farm size, years of farming experience and household size. Farm size and household size had a negative relationship with mixed cropping as a CSA practice in the study area. This implies that the probability of a farming household to practice CSA is decreased as the farm size gets bigger. This is in line with apriori expectation because most of the commercial farms within the study area practice sole cropping unlike smaller farms that practice mixed cropping. The probability of larger households to adopt mixed cropping is less. The 
relationship between years of experience and the adoption of mixed cropping as a CSA practice is positive, implying that experienced farmers will tend to adopt mixed cropping to guard against the negative impact of climate change on crop agriculture.

The planting of cover crops as a CSA practice in the study area was positively influenced by household size of the farmers. This implies that the probability of the farming households to adopt and plant cover crops was increased as a result of an increase in the household size. In other words, larger households will tend to plant cover crops on their farms as a CSA practice to mitigate the negative impact of climate change on crop agriculture.

The result showed that a negative relationship existed between level of education and multiple planting dates as a CSA measure in the study area, implying that the probability of the farming households to stagger the planting dates of their crops is decreased as they acquire more education. This is because as the farmers become educated, they tend to understand the agronomy of crops and the underlying disadvantages of differing the planting dates of crops. This will affect the activities such as fertilizer and herbicide application and time of harvesting.

The result further showed that age negatively affected the adoption of irrigation or dry season farming as a CSA practice. This mean that the probability of farmers in the study area to adopt irrigation decreases as the farmers advanced in age. This is in line with apriori expectation because as the farmers advance in age, their strength decreases. Irrigation is generally tasking as the farmer is expected to move water pumping materials from the house to the farm, open and close water channels among several others.

Table 2 also revealed that the relationship between planting of improve crop variety and years of farming experience and income of the farmers was negative. This mean that the probability of the farmers adopting improved crop varieties decreases as their years of experience increases and as their income also increases. The non-adoption of improved crop varieties as a CSA practice by the farmers within the study area is premise on the requirement of fertilizer by this category crop varieties. This makes the farmers to opt for the tested and tried local varieties which are tolerant to environmental vagaries and they are also hardy.

Finally results in Table 2 showed that the relationship between age of the farmers and the adoption of late planting as a CSA practice was negative. This implies that they will rather wait until when the rains have fully settle before they plant their crops. This agrees with apriori expectation that older farmers are risk averse unlike younger farmers. The study area is situated within the Sahel savannah of the country where after the first rain, periods of drought are often experienced before the rain establish.

Table 2 - Marginal effects from Multinomial Logit (MNL) analysis of factors that determine the adoption of Climate Smart Agriculture in Birnin Kudu, Jigawa State

\begin{tabular}{|c|c|c|c|c|c|c|}
\hline Variable & $\begin{array}{l}\text { Mixed } \\
\text { cropping }\end{array}$ & $\begin{array}{l}\text { Cover } \\
\text { cropping }\end{array}$ & $\begin{array}{l}\text { Multiple planting } \\
\text { dates }\end{array}$ & Irrigation & $\begin{array}{l}\text { Improve } \\
\text { variety }\end{array}$ & $\begin{array}{l}\text { Late } \\
\text { planting }\end{array}$ \\
\hline Age & $\begin{array}{l}2.354 \\
(0.093)\end{array}$ & $\begin{array}{l}-3.849 \\
(-0.290)\end{array}$ & $\begin{array}{l}0.353 \\
(0.172)\end{array}$ & $\begin{array}{l}-3.632 \\
(-0.001)^{\star \star *}\end{array}$ & $1.657(0.081)$ & $\begin{array}{l}-6.240 \\
(-0.003)^{\star *}\end{array}$ \\
\hline Marital status & $\begin{array}{l}-6.340 \\
(-0.192)\end{array}$ & $\begin{array}{l}-1.677 \\
(-0.091)\end{array}$ & $\begin{array}{l}1.188 \\
(0.268)\end{array}$ & $\begin{array}{l}3.159 \\
(0.093)\end{array}$ & $\begin{array}{l}-1.639 \\
(-0.054)\end{array}$ & $\begin{array}{l}-5.475 \\
(-0.183)\end{array}$ \\
\hline Education & $\begin{array}{l}4.538 \\
(0.081)\end{array}$ & $\begin{array}{l}-1.799 \\
(-0.078)\end{array}$ & $\begin{array}{l}-1.625 \\
(-0.033)^{*}\end{array}$ & $\begin{array}{l}1.173 \\
(0.033)^{*}\end{array}$ & $\begin{array}{l}-9.617 \\
(-0.240)\end{array}$ & $\begin{array}{l}6.702 \\
(0.203)\end{array}$ \\
\hline Farm size & $\begin{array}{l}-3.080 \\
(-0.051)^{*}\end{array}$ & $\begin{array}{l}-2.868 \\
(-0.087)\end{array}$ & $\begin{array}{l}-1.398 \\
(-0.202)\end{array}$ & $\begin{array}{l}-1.649 \\
(-0.235)\end{array}$ & $\begin{array}{l}7.330 \\
(0.076)\end{array}$ & $\begin{array}{l}-3.684 \\
(-0.076)\end{array}$ \\
\hline $\begin{array}{l}\text { Years of } \\
\text { experience }\end{array}$ & $\begin{array}{l}2.620 \\
(0.052)\end{array}$ & $6.339(0.274)$ & $\begin{array}{l}-6.170 \\
(-0.127)\end{array}$ & $\begin{array}{l}-6.217 \\
(-0.142)\end{array}$ & $\begin{array}{l}-1.458 \\
(-0.039)^{*}\end{array}$ & $\begin{array}{l}-8.722 \\
(-0.284)\end{array}$ \\
\hline Household size & $\begin{array}{l}-1.160 \\
(-0.019)^{\star \star}\end{array}$ & $\begin{array}{l}1.135 \\
(0.035)^{\star}\end{array}$ & $\begin{array}{l}-9.649 \\
(-0.145)\end{array}$ & $\begin{array}{l}-9.242 \\
(-0.176)\end{array}$ & $\begin{array}{l}5.074 \\
(0.114)\end{array}$ & $\begin{array}{l}1.381 \\
(0.194)\end{array}$ \\
\hline Income & $4.146(0.096)$ & $2.280(0.097)$ & $\begin{array}{l}2.911 \\
(0.065)\end{array}$ & $\begin{array}{l}-6.375 \\
(-0.197)\end{array}$ & $\begin{array}{l}-4.194 \\
(-0.032)\end{array}$ & $\begin{array}{l}-7.057 \\
(-0.151)\end{array}$ \\
\hline $\begin{array}{l}\text { LR Chi } \\
\text { Prob }<X^{2} \\
\text { Pseudo } R^{2} \\
\text { Log Likelihood }\end{array}$ & $\begin{array}{l}-11.1414 \\
0.000 \\
0.66 \\
-1152.823\end{array}$ & & & & & \\
\hline
\end{tabular}


From the result in Table 3, the farmers perceived that the effect of climate change on food crop production was moderately intense and manifested itself through Flooding and Drought. Other effects included high temperature, pest infestation, frequent sickness; disease outbreak and weed resistant were moderately intense as reflected by their means.

Table 3 - Perceived effect of climate change on crop farmers

\begin{tabular}{lllllll}
\hline Variables & $\mathrm{NI}$ & $\mathrm{Ml}$ & $\mathrm{HI}$ & Raw & Mean & Rank \\
\hline Flooding & 58 & 31 & 21 & 257 & 2.34 & $1^{\text {st }}$ \\
Drought & 51 & 43 & 18 & 257 & 2.29 & $2^{\text {nd }}$ \\
Disease Outbreak & 51 & 40 & 22 & 255 & 2.26 & $3^{\text {rd }}$ \\
Pest infestation & 44 & 49 & 22 & 252 & 2.19 & $4^{\text {th }}$ \\
Frequent Sickness & 43 & 50 & 23 & 252 & 2.17 & $5^{\text {th }}$ \\
Weed resistance & 39 & 49 & 27 & 242 & 2.10 & $6^{\text {th }}$ \\
High temperature & 36 & 48 & 32 & 236 & 2.03 & $7^{\text {th }}$ \\
\hline
\end{tabular}

$\mathrm{N}=$ not intense $\mathrm{MI}=$ moderately intense $\mathrm{HI}=$ highly intense.

\section{CONCLUSION}

The study indicated that farmers in the study area were very much aware of the negative effects of climate change on crop production. They therefore consciously or unconsciously adopt and implement measures to minimize its effects. The implement measures such as early planting of crops, mixed cropping, planting cover crops and staggering the planting dates. Others are dry season (irrigation) farming, planting improved variety and late planting. Factors that influence the particular CSA to adopt were found to include age of household head, headship of households, level of education, farm size, years of experience in farming, household size, and income from farming. It is recommended that to further encourage farmers to adopt CSA and thus mitigate the negative effect of climate change, there is need to embark on targeted education. The type of land tenure prevailing in a community has been shown to influence the CSA measures to be adopted and implemented. Therefore the education should be such that will create awareness of the preferred CSA measure to fit the tenure arrangement.

\section{REFERENCES}

1. Adger W.N., S. Huq, K. Brown, D. Conway and M. Hulme. (2003). Adaptation to climate schange in the developing world. Progress in Development Studies 3: 179-195.

2. Beddington J, Asaduzzaman $M$, Clark M, Bremauntz AF, Guillou M, Howlett D, Jahn M, Lin E, Mamo T, Negra C (2012). What Next for Agriculture after Durban. Science 335:289-290. Available online at: http://dx.doi.org/10.1126/science.1217941. PMid:22267797http://dx.doi.org/10.1126/science.1217941.

3. Deressa T, Hassan RM, Alemu T et al (2008) Analyzing the Determinants of Farmer's Choice of Adaptation Methods and Perceptions of Climate Change in the Nile Basin of Ethiopia. International Food Policy Research Institute Discussion Paper 00798.

4. Food and Agriculture Organization of the United Nations. (2010). "Climate-Smart" Agriculture: Policies, Practices and Financing for Food Security, Adaptation and Mitigation. Hague Conference on Agriculture, Food Security and Climate Change.

5. FAO (2018). Climate Smart Agriculture. Building Resilience to Climate Change. Italy.

6. Feder G, Just RE, Zilberman D (1985) Adoption of Agricultural Innovations in Developing Countries: A Survey. Economic Development and Cultural Change 33(2):255-298.

7. Fischer, E. M., and R. Knutti. (2015). Anthropogenic contribution to global occurrence of heavy-precipitation and high-temperature extremes. Nature Climate Change 5: 560-564.

8. Fuster J (2002) Physiology of executive functions: The perception-action cycle. In: Stuss DT, Knight R (eds) Principles of the frontal lobe. Oxford University Press, New York, $p$ 96-108. 
9. Gbetibouo GA (2009) Understanding Farmers' Perceptions and Adaptations to Climate Change and Variability: The case of the Limpopo Basin, South Africa. International Food Policy Research Institute Discussion Paper 00849.

10. Greene, W. H. (2003). Econometric Analysis. New Jersey: Pearson Education.

11. Intergovernmental Panel on Climate Change (IPCC) (2007). Impact, Adaptation and vulnerability contribution of working group 1 to the third assessment report of the intergovernmental panel of climate change London: Cambridge University press.

12. Kahneman D. et al (1990) Experimental Tests of the Endowment Effect and the Coase Theorem. The Journal of Political Economy 98(6): 1325-1348.

13. Kandlinkar, M. and J. Risbey. 2000. Agricultural impacts of climate change: if adaptation is the answer, what is the question? Climatic Change 45: 529-539.

14. Maddison D (2007) The Perception of Adaptation to Climate Change in Africa. Policy Reseach Working Paper WPS4308, The World Bank.

15. McCarthy N, Winters P, Linares AM, Essam T (2012). Indicators to Assess the Effectiveness of Climate Change Projects. Inter-American Development Bank. ImpactEvaluation Guidelines: Technical. Notes, No. IDB-TN-398:1-37.

16. Moore, N., Alagarswamy, G., Pijanowski, B., Thornton, P.K. Lofgren, B. Olson, J., Andresen, J., Yanda, P., Qi, T. and Campbell, D. 2009. Food production risks associated with land use change and climate change in East Africa. IOP Conference Series. Earth and Environmental Science 6:342003.

17. Naess LO (2011). Climate-Smart Agriculture: the new holy grail of agricultural development? Future Agricultures .Available on line at: http://www.futureagricultures.org/component/content/article/38-blog/7643-climate-smart-agriculture-thenew-holy-grail-of-agricultural-development.

18. Norris E, Batie S (1987) Virginia farmers' solid conservation decisions: An application of Tobit analysis. Southern Journal of Agricultural Economics 19:89-97.

19. Ostrom E, Janssen MA Anderies, JM (2007). Going Beyond Panaceas. Proceedings of the National Academy of Sciences, 104:15176-15178. Available online at: http://dx.doi.org/10.1073/pnas.0701886104.

20. Reilly, J.M., Schimmelpfennig, D. (1999). Agricultural impact assessment, vulnerability and the scope for adaptation. Climate Change 43:745-788.

21. Reilly, J. (1995) Climate change and agriculture: Recent findings and issues. American Journal of Agricultural Economics 77(Aug), 727-733.

22. Rockstrom, J. (2000). Water resources management in smallholder farms in eastern and southern Africa, an overview. Physics and Chemistry of The Earth Part B-hydrology Oceans and Atmosphere 25: 275-283.

23. Schiermeier, Q. (2007). Get practical, urge climatologists. Nature 448:234-235. Scholes, R.J., Kuper, W. and Biggs, R. 2006. Boidiversity. Chapter 7. pp. 226 - 261. In: Africa.

24. Seitz, J. and Nyangena, W. (2009). Economic impact of climate change in the East African community (EAC). Final Report, GTZ Project Support to the Integration Process in the EAC Region. Arusha, Tanzania.

25. Scholes, R.J., Kuper, W. and Biggs, R. (2006). Boidiversity. Chapter 7. pp. 226 - 261. In: Africa Environmental Outlook 2: Our environment, our wealth. United Nations Environment Programme, Nairobi, Kenya. ISBN: 92-807-2691-9.

26. Tversky A, Kahneman D (1992) Advances in Prospect Theory: Cumulative Representation of Uncertainty. Journal of Risk and Uncertainty 5(4):297-323.

27. Weber EU (2010). What shapes perceptions of climate change? Wires Climate Change 332-342.

28. Wilby, R. (2007). Decadal climate forecasting techniques for adaptation and development planning: a briefing document on available methods, constraints, risks and opportunities. Department for International Development, UK.

29. Wollenberg E, Campbell BM, Holmgren P, Seymour F, Sibanda L, and von Braun J. (2011). Actions needed to halt deforestation and promote climate-smart agriculture. CCAFS policy Brief no. 4, Copenhagen: CGIAR Research Program on Climate Change, Agriculture and Food Security (CCAFS). 